\title{
Lung transplantation: Chronic allograft dysfunction and establishing immune tolerance
}

\author{
Adam S.A. Gracon ${ }^{\mathrm{a}}$ and David S. Wilkes ${ }^{\mathrm{b},{ }^{*}}$ \\ aDepartment of Surgery and Center for Immunobiology, Indiana University School of Medicine, \\ Indianapolis, IN, USA \\ bepartments of Medicine, Microbiology and Immunology, Center for Immunobiology, Indiana \\ University School of Medicine, Indianapolis, IN, USA
}

\begin{abstract}
Despite significant medical advances since the advent of lung transplantation, improvements in long-term survival have been largely unrealized. Chronic lung allograft dysfunction, in particular obliterative bronchiolitis, is the primary limiting factor. The predominant etiology of obliterative bronchiolitis involves the recipient's innate and adaptive immune response to the transplanted allograft. Current therapeutic strategies have failed to provide a definitive treatment paradigm to improve long-term outcomes. Inducing immune tolerance is an emerging therapeutic strategy that abrogates allograft rejection, avoids immunosuppression, and improves long-term graft function. The aim of this review is to discuss the key immunologic components of obliterative bronchiolitis, describe the state of establishing immune tolerance in transplantation, and highlight those strategies being evaluated in lung transplantation.
\end{abstract}

\section{Keywords}

Chronic lung allograft dysfunction; Obliterative bronchiolitis; Immune tolerance; Transplant tolerance; Transplant immunology

\section{Introduction}

Lung transplant remains the only definitive treatment available for many end-stage pulmonary disorders including chronic obstructive pulmonary disease, idiopathic pulmonary fibrosis, idiopathic pulmonary arterial hypertension, and cystic fibrosis [1]. The utility of lung transplantation as a treatment modality is reflected by the number of transplants performed, which has increased from 5 in 1985 to 3640 worldwide in 2011 [1]. However, despite dramatic improvements in surgical technique, immunosuppressive regimens, and coordinated patient care, the median 5 year survival among recipients is $50 \%$, lower than any other solid organ allograft (Fig. 1) [1,2]. Chronic lung allograft dysfunction (CLAD), in general, and obliterative bronchiolitis/bronchiolitis obliterans syndrome (OB/BOS) in

(C) 2014 American Society for Histocompatibility and Immunogenetics. Published by Elsevier Inc. All rights reserved.

*Corresponding author. Address: Center for Immunobiology, Indiana University School of Medicine, 680 Walnut, Walther Hall, R3 C400, Indianapolis, IN 46202, USA. Fax: +1 317278 7030. dwilkes@iupui.edu (D.S. Wilkes). 
particular, are the predominant factor limiting long-term survival after lung transplant. CLAD, previously known as chronic rejection, can be represented by different histologic patterns with $\mathrm{OB}$ being the most common. OB occurs in the small conducting airways, sparing the more distal respiratory bronchioles. As seen in Fig. 2, partial or complete airway occlusion arises as a result of proliferation of connective tissue, which may include microvascular-rich granulation in the context of abnormal tissue repair and remodeling [3]. BOS is the clinical correlate of $\mathrm{OB}$ and is diagnosed on the basis of forced expiratory volume in $1 \mathrm{~s}\left(\mathrm{FEV}_{1}\right)$ [4]. Within 5 years of transplant nearly $49 \%$ of recipients have BOS, a number that increases to $76 \%$ at 10 years and represents the most common cause of death among recipients following the first post-transplant year [1]. At present, once initiated there is no effective treatment to reverse the obliterative process. The aim of this review is to describe the immunopathophysiology of $\mathrm{OB}$ and outline the current state of establishing immune tolerance in transplantation, particularly in the setting of lung allografts.

\section{Immunopathophysiology of obliterative bronchiolitis}

The pathogenesis of OB has not been fully characterized but is known to be multifactorial and includes components of cellular and humoral alloimmunity, innate immunity, and both cellular and humoral autoimmunity. The cellular immune response to allo- and autoantigens is dependent on the migration of antigen presenting cells (APCs) to secondary lymphoid organs, including the spleen and lung's regional lymph nodes where reactive $\mathrm{T}$ cells are activated [5]. T cells may also be stimulated directly by dendritic cells within the lung [6]. As depicted in Fig. 3, T cell receptors can recognize intact allogeneic major histocompatibility complex (MHC) on donor cells (direct pathway), peptide fragments of allogeneic MHC presented by recipient MHC molecules (indirect pathway), or possibly the semidirect pathway that involves intact donor derived MHC-peptide complexes presented by recipient antigen presenting cells to recipient $\mathrm{T}$ cells $[6,7]$. However, unlike other solid organ transplants, there is little evidence of the semidirect pathway involved in lung transplant rejection. Following the recognition of $\mathrm{MHC}$ antigen, $\mathrm{T}$ cells require secondary costimulatory signals, which result in a cascade of secondary signaling leading to proliferation and differentiation. The primary $\mathrm{T}$ cell type responsible for ongoing immune reactivity includes Th1 and Th17, which are key sources of interferon- $\gamma$ and IL-17, respectively, which facilitate further the immune response [8].

The role of humoral alloimmunity has been suggested by clinical findings where MHC antibodies that develop after transplant have been demonstrated to confer an increased risk of BOS and decreased survival [9]. The allogeneic antibody targets include MHC and minor histocompatibility antigens. Following transplant, T cell dependent donor specific B cells develop resulting in anti-donor antibody production by plasma cells. Antibodies bind their donor antigenic target, as well as complement factor C1q, resulting in activation of the complement cascade [10]. The involvement of antibody mediated rejection in OB has been suggested by findings that donor specific antibodies precede the onset of BOS and are strongly associated with its development [11]. Furthermore, it is mechanistically supported by studies demonstrating anti-HLA antibodies induce fibrogenic growth factor production, proliferative changes, and apoptotic death in airway epithelial cells [12]. However, unlike 
OB that occurs in graft versus host disease post hematopoietic stem cell transplants, there is no direct evidence that alloantibodies, alone, induce OB post lung transplantation [13].

The innate immune response in lung transplant rejection is an emerging concept and of particular interest given the allograft's unique environmental exposure. Ischemia reperfusion injury (IRI) following transplant has been found to induce inflammation through activation of toll-like receptors (TLR) and signaling via TLR signal adaptor MyD88 [14]. Primary graft dysfunction (PGD), thought to be at least partially induced through this pathway, has been associated with increased rates of BOS [15]. Furthermore, polymorphisms in TLR4 that alter the response to endotoxin, have been associated with a trend toward reduced onset of BOS [16]. Our group recently confirmed that the development of OB is at least partly dependent on complement. It was shown that complement regulatory proteins CD55 and Crry (CD46) are downregulated during OB in both humans and mice, while bronchoalveolar lavage (BAL) fluid C3a, an anaphylotoxin, is increased. This process was found to be mediated by IL-17 [17].

One critical pathophysiologic feature of OB is a cycle of repeated injury and repair [18]. Injury may be induced by IRI, alloimmune, or innate immune responses and results in the release of inflammatory products, matrix metalloproteases, and other mediators that ultimately lead to tissue remodeling. This process of remodeling exposes autoantigens previously concealed from the immune system [19]. A substantial amount of work in the area of autoimmunity has demonstrated type $\mathrm{V}$ collagen $[\mathrm{Col}(\mathrm{V})]$ to be a critical self-antigen liberated by this process. $\mathrm{Col}(\mathrm{V})$ is present in the lung, skin, and placenta as a triple helix heterodimer composed of $a_{1}$ and $a_{2}$ chains [20]. Within the lung it is located in the perivascular and peribronchial tissues, as well as the epithelium - all sites of chronic rejection [21]. $\mathrm{Col}(\mathrm{V})$ is assembled in the same fibril as collagen Type I, effectively masking it's molecular epitopes from the immune system [22]. When the lung parenchyma is subjected to repeated injury, these antigenic proteins are exposed allowing for an autoimmune response. Col(V) cellular autoimmunity has been demonstrated in both preclinical and clinical studies. Using a rat lung orthotopic transplant model, our laboratory has demonstrated $\mathrm{T}$ cell responses to $\operatorname{col}(\mathrm{V})$ after the onset of $\mathrm{OB}$ in allograft recipients, a response not present for third-party antigens or in naïve animals $[23,24]$. This finding was confirmed clinically by Burlingham et al. in a study of human transplant recipients. Here it was shown that patients with strongly positive $\mathrm{T}$ cell response to $\operatorname{col}(\mathrm{V})$ had the highest incidence of severe BOS [8].

The humoral response to self-antigen in the context of lung transplantation has also been explored. Autoantibodies to col(V) and K-a1 tubulin have been specifically implicated in the development of BOS in preclinical models [25,26]. K-a1 tubulin (Ka1T) is a protein component of microtubules, which provide cytoskeletal structure and are critical for normal cellular function [27]. Ka1T exposure may result from chronic injury to the airway epithelium or as a result of cell surface expression under select circumstances. Anti-Ka1T binding to airway epithelial cells results in expression of transcription factors involved in fibroproliferation, a hallmark of OB [25]. Clinically, the presence of anti-col(V) and antiKa1T antibodies following transplant have been strongly correlated with the development of 
BOS [28]. Furthermore, a subset of patients have anti-col(V) and anti-Ka1T pre-transplant, which confer an increased risk of BOS as well [29].

\section{Immune tolerance}

A critical feature of the normal immune system is establishing effective cell-mediated and humoral responses to foreign antigens while remaining unresponsive to self-antigens [30]. This occurs both centrally and peripherally as seen in Fig. 4. Central tolerance refers to triggered cell death of intrathymic immature $\mathrm{CD} 4^{+} \mathrm{T}$ cells with high affinity for self-antigen, termed negative selection. This process limits the maturation of self-reactive cells and their subsequent relocation to the periphery. Peripheral tolerance pertains to the regulation of mature $\mathrm{T}$ cells in peripheral tissues by anergy, deletion, and/or production of regulatory $\mathrm{T}$ cells (Tregs). Anergy represents a state of inactivation that results from insufficient costimulation of self-reactive $\mathrm{T}$ cells, while deletion likely results from apoptosis induced upon recognition of self-antigen [31,32]. Tregs modulate the activity of reactive $\mathrm{T}$ cells through production of regulatory cytokines that include IL-10, TGF- $\beta$, or IL-35 [33]. As a key regulatory immune cell, Tregs have been implicated as a mechanistic component of most approaches used to induce tolerance.

The goal of establishing tolerance in transplantation is to deliberately abate the detrimental allograft-specific immune response, while eliminating long term immunosuppression and maintaining a competent immune system [34]. Definitions of tolerance that may be of greater use clinically include clinical operational tolerance (COT) and prope tolerance. COT refers to "perfectly normal graft function in the total absence of maintenance immunosuppression" that occurs in patients that maintain "all other immune responses intact" [35]. Prope tolerance or "almost" tolerance refers to circumstances where normal graft function requires maintenance immunosuppression, albeit in very low doses [36]. In addition to clear definitions of tolerance, establishing biochemical indications of whether tolerance has occurred is of critical importance. In 2010, Newell and colleagues made progress in this regard by examining kidney transplant recipients who had developed tolerance [37]. It was demonstrated that tolerant patients had expanded numbers of NK cells as well as total and naïve B cells, with differential expression of three B cell genes. These three genes predicted tolerance with $100 \%$ accuracy in a patient test set and as a result represented a step forward with regard to tolerance biomarker identification. In a concurrent study by Sagoo and colleagues, similar findings were made with regard to the expansion of $\mathrm{B}$ and NK cells in peripheral blood of tolerant recipients [38]. Additionally, other bioassays revealed that tolerant individuals lacked donor-specific antibodies, had fewer activated $\mathrm{CD} 4^{+} \mathrm{T}$ cells and donor-specific hyporesponsiveness of $\mathrm{CD} 4^{+} \mathrm{T}$ cells, and had a high ratio of forkhead box P3 to a-1,2-mannosidase gene. Together, the authors offered these findings as a "cross-platform biomarker signature" that could be used to identify tolerant individuals [38]. 


\section{Approaches to transplant tolerance}

\subsection{Antigen-coupled cells}

Antigen-coupled cells are developed by 1-ethyl-3-(3'-dimethyl-aminopropyl)-carbodiimide (ECDI) treatment of peripheral blood cells or splenocytes. This approach allows for the targeting of $\mathrm{T}$ cells with varying specificity given multiple peptides can be coupled to a single cell [39]. After administration, tolerance induction occurs as a result of cell apoptosis and uptake by the spleen, followed by T cell anergy involving IL-10, TGF- $\beta$, and costimulatory pathways including PD-1/PD-L1. This is followed by a Treg mediated maintenance phase [40,41]. Using an MHC-mismatched islet transplantation model in mice, Luo et al. demonstrated that ECDI-treated donor splenocytes administered to recipients pre and post-transplant resulted in prolonged allograft tolerance without immunosuppression [42]. This included a complete absence of donor-specific antibodies and delayed-type hypersensitivity (DTH) response among tolerized recipients. This approach was further evaluated in a fully MHC-mismatched cardiac allograft model, where tolerance was achieved when ECDI was combined with a short course of rapamycin [43]. Recently, a phase I clinical study sought to evaluate antigen-coupled cells for the treatment of autoimmune disease [44]. Here it was shown that multiple sclerosis (MS) patients who received higher doses of autologous peripheral blood mononuclear cells coupled with myelin peptides had decreased antigen specific $\mathrm{T}$ cell response. Furthermore, the safety profile and tolerability was found to be acceptable.

\subsection{TCR/CD3 complex targeting}

The T cell receptor (TCR) recognizes antigenic peptides presented by MHC of APCs. However, the TCR lacks the ability to transmit intracellular signals without CD3. Therefore, expression of TCR occurs in combination with CD3 and combined their respective protein chains form the TCR complex. The intracellular domain of CD3 chains contain immunoreceptor tyrosine-based activation motifs (ITAMs) that allow signaling to occur upon binding of the TCR [45]. Antibody targeting of the TCR/CD3 complex was initially thought of as a non-specific approach to immune suppression, however subsequent studies have found that antigen specific tolerance can be achieved. This process is thought to involve a shift to Th2 cytokine production of IL-4, reactive T cell deletion, and induction of Tregs [46]. Using a mouse IgG3 monoclonal antibody to CD3, Nicolls et al. first demonstrated the ability to achieve tolerance using monoclonal anti-CD3 antibody in a rat cardiac transplantation model [47]. Here it was shown that anti-CD3 mAb induced a state of long-term immune unresponsiveness to fully MHC incompatible cardiac allografts.

Furthermore, treated rats were unresponsive to subsequent donor strain skin grafts, with skin graft survival up to 150 days in the absence of immunosuppression. Anti-CD3-induced immune tolerance has also been achieved in a murine pancreatic islet transplantation model [48]. C57BL/6 mice receiving pancreatic islets from BALB/c donors had $>100$ day allograft acceptance if treated with anti-CD3. The timing of antibody administration was found to be critical as delayed administration significantly prolonged survival. This finding suggested that a primed immune system was necessary for anti-CD3 antibody mediated tolerance. To date, translation to the clinic has focused on autoimmune processes, namely Type I Diabetes. This has included Phase I, II, and III studies of otelixizumab and teplizumab, 
humanized Fc mutated antibodies to $\mathrm{CD} 3$, where short treatment courses have conferred benefit with regard to maintenance of insulin secretion for up to 24 months when adequately dosed [49]. However, because differences exist between the autoimmune response to pancreatic cells that occurs with diabetes and the immune response to transplanted allograft, further studies will be required to demonstrate the utility of anti-CD3 antibody in the transplant population.

\section{3. $T$ cell costimulation blockade}

$\mathrm{T}$ cell activation is a regulated process requiring secondary signaling in combination with cognate interactions of the T cell receptor with MHC expressed on antigen presenting cells. A variety of therapeutic targets involving costimulatory signaling have been evaluated for use in the induction of immune tolerance. The CD28:CD80/CD86 pathway represents the most frequently studied target and involves CD80 (B7-1) and CD86 (B7-2) on the surface of APCs binding CD28 on T cells. Binding of CD28 is required for T cell activation to occur following antigen presentation to the TCR. CD80 and CD86 are also involved in a second, coinhibitory pathway, that occurs as a result of binding to cytotoxic $\mathrm{T}$ lymphocyteassociated antigen 4 (CTLA-4 also known as CD152) on previously activated T cells [50]. CTLA-4 is structurally similar to CD28, but binds CD80 and CD86 with significantly higher affinity. Therefore CD28 costimulatory signaling is interrupted leading to incomplete $\mathrm{T}$ cell activation, anergy, and apoptosis [51]. Capitalizing on this pathway has included anti-CD80/ CD86 monoclonal antibodies, anti-CD28 monoclonal antibodies, and CTLA-4 immunoglobulin (Ig) fusion proteins [52]. Blocking CD80/86 has been shown to result in prolonged allograft survival in a non-human primate (NHP) model of renal transplantation. However, even when combined with other immunosuppressant agents, this approach has not been shown to achieve tolerance [53]. Conversely, Haspot et al. demonstrated that antiCD28 administered immediately following transplant resulted in renal allograft tolerance among fully MHC mismatched rats [54].

CTLA-4-Ig, comprised of the Fc domain of human IgG1 linked to the extracellular component of CTLA-4, represents the most thoroughly studied approach to inducing immune tolerance with costimulatory blockade. Early studies demonstrated that CTLA-4-Ig could abrogate $\mathrm{T}$ cell dependent $\mathrm{B}$ cell antibody production and limit rejection of cardiac allografts [55]. This was followed by Pearson and colleagues who demonstrated tolerance among mouse cardiac allograft recipients. Here it was shown that the majority of recipients receiving a 12 day course of CTLA-4-Ig following transplant with fully mismatched grafts resulted in indefinite (>100 day) survival. Donor specific tolerance was subsequently confirmed by acceptance of donor-specific skin grafts while third-party grafts were rejected [56]. Despite promising results in these rodent transplant models, among others, CTLA-4-Ig was unable to induce tolerance in NHP and humans. With modification however, it was translated to the clinic as belatacept and approved for use with renal transplantation induction and maintenance.

The CD40:CD154(CD40L) pathway represents a second extensively studied target for extending allograft survival. CD40 is expressed on B cells, APCs, and macrophages. Endothelial expression may also be induced as a result of inflammation [52]. CD154 is 
expressed on T cells following antigen induced activation. Cell-surface CD154 or soluble CD154 binding to CD40 results in signaling via tumor necrosis receptor associated factor (TRAF) and nuclear factor- $\kappa \mathrm{B}(\mathrm{NF}-\kappa \mathrm{B})$ pathways. This serves to promote antigen presentation and cytokine production, further activating T cells. Similarly, binding to B cells is essential for antibody production and proliferation [57,58]. The therapeutic potential of this pathway has been clearly established in small animal models. Hancock et al. demonstrated that by combining anti-CD154 with donor specific transfusions, allograft function was extended beyond 150 days in a cardiac allograft rat model [59]. Combining anti-CD154 mAb and CTLA-4-Ig, Larson et al. showed a synergistic effect could be realized. Using this approach, he was able to demonstrate a greater than 50 day survival of fully mismatched murine skin allografts, as well as inhibition of chronic vasculopathy in the cardiac allograft model [60]. Jiang et al. confirmed the finding of extended cardiac graft survival in this model and further demonstrated tolerance was attributable to donor Tregs, which were critical following transplant, but not required for maintenance of tolerance [61]. Despite further successes with anti-CD154 mAb in multiple models including NHP, translation to the clinic was limited by thromboembolic events. This was an unintended consequence of antibody interaction with CD154 on platelets which lead to platelet activation and subsequent vascular compromise [62]. As a result, targeting this pathway has shifted to the use of anti-CD40 mAb. This alternative approach has also shown promising results. Combining anti-CD40, anti-CD86, and a short course of low dose cyclosporine, Haanstra et al. demonstrated prolonged survival of renal allografts in rhesus monkeys [63]. In this study, two of four animals had 3-year drug free survival following initial treatment.

Given these successes, additional pathways of interest for mitigating the immune response in transplant continue to emerge. These include inducible T cell costimulator (ICOS), programmed cell death protein 1 (PD-1 or CD279), OX40 (CD134), 4-1BB (CD137), CD27, lymphocyte function-associated antigen 1 (LFA-1), CD2, T cell Ig and mucin 1 (TIM-1), B7-H3/4 and their respective ligands [64].

\subsection{Mixed chimerism}

Mixed chimerism refers to transplantation of hematopoietic stem cells to a recipient establishing a coexistent host and donor lymphohematopoietic system [7]. Early murine studies by Illstad and Sachs were the first to demonstrate the utility of this approach in transplant tolerance [65]. It was shown that mice undergoing irradiation followed by mixed donor and recipient lymphohematopoietic reconstitution accepted subsequent donor type skin grafts while rejecting third-party allografts. Achieving these results in mice has historically required recipient cytoablative conditioning with complete destruction of mature donor-reactive T cells. However, new protocols and techniques, including the use costimulatory blockade, have helped to improve the toxicity profile [66]. As reviewed by Sachs, Kawai, and Sykes, establishing tolerance by inducing mixed chimerism has had success in preclinical and clinical studies and has been the most successfully translated strategy for transplant tolerance to date [66]. This is exemplified by Kawai's study of endstage renal disease patients receiving combined bone marrow and kidney transplants [67,68]. Following conditioning, five patients received living related kidneys donated by relatives that were mismatched for one HLA haplotype. The conditioning regimen included 
preoperative cyclophosphamide, anti-CD2 mAb, and thymic irradiation. Following transplant, subjects received donor bone marrow and several months of cyclosporine. This protocol was changed during the study to also include preoperative rituximab and a short postoperative course of prednisone. All patients developed transient chimerism and four of the five patients were withdrawn from all immunosuppressive agents by $9-14$ months. Three of the four patients remained free from immunosuppression for over 5 years and one developed chronic rejection at year 5 . The regimen used for these patients was further modified to include two additional doses of rituximab and studied in five subsequent patients. Three were able to discontinue immunosuppression and were free from rejection at the 3 year mark [68]. With these promising results, this strategy may prove the closest to expanded clinical use.

\subsection{Regulatory cells}

Several groups of "suppressive" or T regulatory cells have been found in vivo or induced experimentally. The most frequently occurring and well defined Treg is the CD $4^{+} \mathrm{CD} 25^{+}$ Foxp $3^{+}$cell. Tregs are a critical component of the normal immune system's ability to remain homeostatic, which is accomplished by the release of immunomodulatory cytokines, as well as direct cell-cell interactions $[69,70]$. This serves to balance the activated immune response, which becomes increasingly important in the context of a transplanted allograft. Preclinical models, as well as clinical lung transplantation have shown that increased proportions of Tregs confer stable allograft function, while a decline of this cell population is associated with chronic rejection [70]. Nearly every strategy to induce allograft tolerance relies on Tregs as a component of induction or long-term maintenance. As a result, therapy incorporating in vivo activation or adoptive transfer of Tregs has become a significant focus. Using a fully MHC-mismatched murine islet transplantation model, Lee et al. demonstrated that indefinite graft survival could be achieved. Recipient mice were conditioned with a transfusion of donor splenocytes followed by cyclophosphamide. Donor specific Tregs were expanded in vitro and administered prior to transplantation. More than $70 \%$ of recipients achieved indefinite graft survival without additional immunosuppression [71]. Joffre et al. incorporated Tregs to induce tolerance to skin and cardiac allografts [72]. Here, in vitro expansion of Tregs specific for both direct and indirect alloantigen presentation were used in conjunction with bone marrow to establish a chimeric state in recipients. Subsequently placed allogeneic skin grafts survived to 100 days without histologic evidence of rejection. Using a similar protocol, equivalent results were demonstrated with cardiac allografts. One significant advantage of using Tregs in the setting of mixed chimerism is the ability to avoid toxic cytoreductive conditioning of the recipient, a requirement of many chimerism induction protocols [73].

The ability to translate these results into an effective therapy will depend heavily on reliable Treg production with adequate purity and stability, as well as documentation of safety. Early phase studies have been initiated to evaluate Treg therapy in the clinic, including studies in graft versus host disease, liver transplantation, and kidney transplantation [74]. These initial studies will provide the preliminary results necessary to evaluate the feasibility of this strategy moving forward for other solid organ allografts, including the lung. 


\subsection{Oral immunotherapy}

Oral immunotherapy (OIT) refers to the oral administration of an antigen with the goal of suppressing a subsequent immune response to the same antigen [75]. Mucosal administration of peptides for antigen-specific induction of tolerance highlights the body's inherent ability to interact with non-self antigens. The gastrointestinal tract mucosa is exposed to a myriad of foreign antigens originating from the bacterial microbiome and foreign ingestion. Despite this, a state of non-pathologic homeostasis is maintained [76]. Advantages of OIT include ease of preparation, administration, and decreased toxicity. Preclinical studies evaluating the use of OIT in models of autoimmune disease including multiple sclerosis, diabetes, and arthritis have shown encouraging results with regard to mitigating the disease process. Two dominant contributory mechanisms have been identified: (1) secretion of modulatory cytokines by Tregs and (2) clonal deletion or anergy of antigen specific T cells [77]. In transplantation, this approach has a distinct advantage compared to autoimmune processes given allo and autoantigens have been defined and may be administered prior to the recipient immune system's detrimental effects [78]. The first report describing the oral administration of MHC antigen and its effect on the systemic alloimmune response was by Sayegh et al. Here it was shown that feeding allogeneic splenocytes prevented sensitization to skin allografts and altered cardiac allograft rejection, slowing the pace of rejection from "accelerated" to acute [79]. The group also demonstrated an antigen-specific tolerogenic effect following the oral administration of synthetic class II MHC peptides, where it was shown that the DTH response to peptides and donor-derived cells was inhibited [80]. Niimi et al. combined the oral administration of alloantigen with anti-CD4 monoclonal antibody. Using this technique, cardiac allografts survived indefinitely in recipient mice [81]. A subsequent pilot study initiated by Womer and colleagues incorporated oral administration of class II MHC peptides in a cohort of renal transplant recipients who had evidence of alloreactivity and epitope spreading [78]. Complete suppression of alloreactivity was achieved and safety of administration confirmed. As with other models of OIT, the dose was found to be of critical importance illustrated by efficacy at a low dose, but not at higher doses.

\section{Lung transplant tolerance}

Lung allografts are particularly immunogenic. This is evidenced by higher rates of rejection and decreased survival compared to other solid organs. The etiology of their immunogenicity is multifactorial, including repeated exposure to infective and noninfective stimuli in inspired air, as well as microaspiration [82]. As a result, establishing immune tolerance has been limited compared to other organs. This was illustrated by Gelman et al. who demonstrated that costimulatory blockade with CTLA-4-Ig alone was incapable of producing prolonged survival of pulmonary allografts in a murine vascularized lung transplant model [83]. This is in contrast to previous successes with this approach in other murine organ transplantation models. Similarly, inducing mixed chimerism has yielded worse outcomes among lung allograft recipients despite significant success with renal allograft transplantation. This was elucidated by Aoyama et al. who utilized fully MHC mismatched cynomolgus monkeys [84]. With a protocol previously successful with renal allografts, recipients were conditioned with total body irradiation, thymic irradiation, and 
anti-thymocyte globulin. Following transplant, each received anti-CD154 and a short course of cyclosporine. Transient chimerism was achieved, but allografts were rejected in a significantly shorter time period than what was observed in kidneys transplanted under the same conditions.

Despite these results, several approaches have shown various degrees of success in lung transplantation models. Using the mouse orthotopic lung transplant model, Dodd-O et al. demonstrated that costimulation blockade with anti-CD154 Ab abrogated the alloeffector $\mathrm{CD} 8^{+}$and $\mathrm{CD} 4^{+}$responses. This included an increase in the $\mathrm{CD} 4: \mathrm{CD} 8$ ratio with a higher frequency of $\mathrm{CD}^{+} \mathrm{CD} 25^{+} \mathrm{Foxp}^{+} \mathrm{T}$ cells [85]. Okazaki et al. confirmed the utility of costimulation blockade in the allogeneic lung transplant model using anti-CD154 with prolonged survival of allogeneic lung grafts in excess of 100 days [86]. Using MHC class I disparate inbred miniature swine, Shoji et al. demonstrated that a 12 day post-operative course of continuous intravenous tacrolimus without further immunosuppression resulted in long term lung graft survival without evidence of chronic rejection [87]. This was followed by a study with full MHC disparity with similar graft longevity, but some evidence of OB on pathology [88]. A recent development in the prevention of OB includes the use of mesenchymal stem cells. Using a heterotopic tracheal transplant model, Zhao et al. showed that placenta derived human mesenchymal stem cells (PMSCs) attenuated the development of obliterative airways disease that shares some histologic features with OB [89]. PMSCs were administered to the peri-graft subcutaneous tissue following transplant and based on group assignment, the tracheas were harvested at 14 and 28 days. Significant differences were found in luminal obliterations as well as Treg concentration. These preliminary results suggest this approach may have utility, however due to differences between the heterotopic tracheal transplant model and the ventilated and perfused orthotopic lung transplant model, further investigation is warranted to validate these findings [90,91].

Our laboratory has utilized concepts introduced in the field of autoimmune disease to explore the use of autoantigen OIT in transplantation. $\mathrm{Col}(\mathrm{V})$ was initially selected as a tolerizing antigen due to the brisk anti-col(V) $\mathrm{T}$ cell mediated immune response that occurred following lung transplantation in rats [92]. Early experiments employed a rat model of transplantation where WKY $\left(\mathrm{RT}^{\mathrm{lv} 1}\right)$ rats served as recipients and were fed col(V) prior to transplantation of F344 rats $\left(\mathrm{RT}^{\mathrm{l}}\right)$ lung allografts. Oral administration of $\mathrm{col}(\mathrm{V})$ was found to prevent both acute rejection and OB in the absence of any other form of immunosuppression [23,24]. Similar to models of autoimmune disease, suppression of the immune response in the transplant recipient was found to be associated with increased TGF$\beta$. However, contrary to findings in autoimmune models, IL-10 and IL-4 were not detected [24]. These findings instigated the study of rat lung allografts fully incompatible at MHC class I and II loci. Brown Norway $\left(\mathrm{RT}^{\mathrm{n}}\right)$ lungs were transplanted into WKY (RT1 $\left.{ }^{\mathrm{lv} 1}\right)$ rats and comparison was made with col(V) oral administration and cyclosporine versus cyclosporine alone. Compared to cyclosporine alone, $\operatorname{col}(\mathrm{V})$ oral administration plus cyclosporine prevented rejection and down-regulated the alloantigen-induced production of IFN- $\gamma$ and IL-17A. Additionally, chemotaxis for lung macrophages was suppressed in allograft bronchoalveolar lavage fluid. The combination was also associated with Treg involvement including expression of IL-10 in mediastinal lymph node and splenic T cells, intragraft expression of IL-10 and Foxp3 in perivascular and peribronchiolar mononuclear 
cells, and production of IL-10 from allograft alveolar macrophages [93]. Interestingly, this study did not identify an association with TGF- $\beta$ as part of the immunoregulatory pathways.

\section{Conclusion}

Despite incredible advances, each therapeutic strategy to induce tolerance has unique obstacles to overcome. Additionally, evidence clearly demonstrates that the degree of success will depend on the organ transplanted. Compared to other solid organs, lung allograft recipients have the shortest mean survival following transplant. Studies to date suggest that they may also represent the most challenging population for tolerance induction. However, this suggests that potential lung transplant recipients represent the population most likely to benefit from a successful therapeutic approach.

\section{References}

1. Yusen RD, Christie JD, Edwards LB, Kucheryavaya AY, Benden C, Dipchand AI, et al. The registry of the international society for heart and lung transplantation: thirtieth adult lung and heartlung transplant report - 2013; focus theme: age. J Heart Lung Transplant. 2013; 32:965. [PubMed: 24054805]

2. Lodhi SA, Lamb KE, Meier-Kriesche HU. Solid organ allograft survival improvement in the United States: the long-term does not mirror the dramatic short-term success. Am J Transplant. 2011; 11:1226. [PubMed: 21564524]

3. Stewart S, Fishbein MC, Snell GI, Berry GJ, Boehler A, Burke MM, et al. Revision of the 1996 working formulation for the standardization of nomenclature in the diagnosis of lung rejection. $\mathrm{J}$ Heart Lung Transplant. 2007; 26:1229. [PubMed: 18096473]

4. Verleden GM, Raghu G, Meyer KC, Glanville AR, Corris P. A new classification system for chronic lung allograft dysfunction. J Heart Lung Transplant. 2014; 33:127. [PubMed: 24374027]

5. Larsen CP, Morris PJ, Austyn JM. Migration of dendritic leukocytes from cardiac allografts into host spleens A novel pathway for initiation of rejection. J Exp Med. 1990; 171:307. [PubMed: 2404081]

6. Gelman AE, Li W, Richardson SB, Zinselmeyer BH, Lai J, Okazaki M, et al. Cutting edge: acute lung allograft rejection is independent of secondary lymphoid organs. J Immunol. 2009; 182:3969. [PubMed: 19299693]

7. Getts DR, Shankar S, Chastain EM, Martin A, Getts MT, Wood K, et al. Current landscape for Tcell targeting in autoimmunity and transplantation. Immunotherapy. 2011; 3:853. [PubMed: 21751954]

8. Burlingham WJ, Love RB, Jankowska-Gan E, Haynes LD, Xu Q, Bobadilla JL, et al. IL-17dependent cellular immunity to collagen type $\mathrm{V}$ predisposes to obliterative bronchiolitis in human lung transplants. J Clin Invest. 2007; 117:3498. [PubMed: 17965778]

9. Palmer SM, Davis RD, Hadjiliadis D, Hertz MI, Howell DN, Ward FE, et al. Development of an antibody specific to major histocompatibility antigens detectable by flow cytometry after lung transplant is associated with bronchiolitis obliterans syndrome. Transplantation. 2002; 74:799. [PubMed: 12364858]

10. McManigle W, Pavlisko EN, Martinu T. Acute cellular and antibody-mediated allograft rejection. Semin Respir Crit Care Med. 2013; 34:320. [PubMed: 23821507]

11. Lobo LJ, Aris RM, Schmitz J, Neuringer IP. Donor-specific antibodies are associated with antibody-mediated rejection, acute cellular rejection, bronchiolitis obliterans syndrome, and cystic fibrosis after lung transplantation. J Heart Lung Transplant. 2013; 32:70. [PubMed: 23260706]

12. Jaramillo A, Smith CR, Maruyama T, Zhang L, Patterson GA, Mohanakumar T. Anti-HLA class I antibody binding to airway epithelial cells induces production of fibrogenic growth factors and apoptotic cell death: a possible mechanism for bronchiolitis obliterans syndrome. Hum Immunol. 2003; 64:521. [PubMed: 12691702] 
13. Srinivasan M, Flynn R, Price A, Ranger A, Browning JL, Taylor PA, et al. Donor B-cell alloantibody deposition and germinal center formation are required for the development of murine chronic GVHD and bronchiolitis obliterans. Blood. 2012; 119:1570. [PubMed: 22072556]

14. Kreisel D, Goldstein DR. Innate immunity and organ transplantation: focus on lung transplantation. Transpl Int. 2013; 26:2. [PubMed: 22909350]

15. Kreisel D, Krupnick AS, Puri V, Guthrie TJ, Trulock EP, Meyers BF, et al. Short-and long-term outcomes of 1000 adult lung transplant recipients at a single center. J Thorac Cardiovasc Surg. 2011; 141:215. [PubMed: 21093882]

16. Palmer SM, Burch LH, Trindade AJ, Davis RD, Herczyk WF, Reinsmoen NL, et al. Innate immunity influences long-term outcomes after human lung transplant. Am J Respir Crit Care Med. 2005; 171:780. [PubMed: 15640363]

17. Suzuki H, Lasbury ME, Fan L, Vittal R, Mickler EA, Benson HL, et al. Role of complement activation in obliterative bronchiolitis post-lung transplantation. J Immunol. 2013; 191:4431. [PubMed: 24043901]

18. Sumpter TL, Wilkes DS. Role of autoimmunity in organ allograft rejection: a focus on immunity to type V collagen in the pathogenesis of lung transplant rejection. Am J Physiol - Lung Cell Mol Physiol. 2004; 286:L1129. [PubMed: 15136293]

19. Iwata T, Chiyo M, Yoshida S, Smith GN Jr, Mickler EA, Presson R Jr, et al. Lung transplant ischemia reperfusion injury: metalloprotease inhibition down-regulates exposure of type $\mathrm{V}$ collagen, growth-related oncogene-induced neutrophil chemotaxis, and tumor necrosis factoralpha expression. Transplantation. 2008; 85:417. [PubMed: 18322435]

20. Konomi H, Hayashi T, Nakayasu K, Arima M. Localization of type V collagen and type IV collagen in human cornea, lung and skin Immunohistochemical evidence by anti-collagen antibodies characterized by immunoelectroblotting. Am J Pathol. 1984; 116:417. [PubMed: 6383060]

21. Madri JA, Furthmayr H. Isolation and tissue localization of type AB2 collagen from normal lung parenchyma. Am J Pathol. 1979; 94:323. [PubMed: 371411]

22. Birk DE, Fitch JM, Babiarz JP, Linsenmayer TF. Collagen type I and type V are present in the same fibril in the avian corneal stroma. J Cell Biol. 1988; 106:999. [PubMed: 3346334]

23. Yasufuku K, Heidler KM, O’Donnell PW, Smith GN Jr, Cummings OW, Foresman BH, et al. Oral tolerance induction by type $\mathrm{V}$ collagen downregulates lung allograft rejection. Am J Respir Cell Mol Biol. 2001; 25:26. [PubMed: 11472972]

24. Yasufuku K, Heidler KM, Woods KA, Smith GN Jr, Cummings OW, Fujisawa T, et al. Prevention of bronchiolitis obliterans in rat lung allografts by type $\mathrm{V}$ collagen-induced oral tolerance. Transplantation. 2002; 73:500. [PubMed: 11889419]

25. Goers TA, Ramachandran S, Aloush A, Trulock E, Patterson GA, Mohanakumar T. De novo production of K-alpha1 tubulin-specific antibodies: role in chronic lung allograft rejection. $\mathrm{J}$ Immunol. 2008; 180:4487. [PubMed: 18354170]

26. Haque MA, Mizobuchi T, Yasufuku K, Fujisawa T, Brutkiewicz RR, Zheng Y, et al. Evidence for immune responses to a self-antigen in lung transplantation: role of type $\mathrm{V}$ collagen-specific $\mathrm{T}$ cells in the pathogenesis of lung allograft rejection. J Immunol. 2002; 169:1542. [PubMed: 12133982]

27. Yin S, Zeng C, Hari M, Cabral F. Paclitaxel resistance by random mutagenesis of alpha-tubulin. Cytoskeleton (Hoboken). 2013; 70:849. [PubMed: 24155014]

28. Saini D, Weber J, Ramachandran S, Phelan D, Tiriveedhi V, Liu M, et al. Alloimmunity-induced autoimmunity as a potential mechanism in the pathogenesis of chronic rejection of human lung allografts. J Heart Lung Transplant. 2011; 30:624. [PubMed: 21414808]

29. Tiriveedhi V, Gautam B, Sarma NJ, Askar M, Budev M, Aloush A, et al. Pre-transplant antibodies to Kalpha1 tubulin and collagen-V in lung transplantation: clinical correlations. J Heart Lung Transplant. 2013; 32:807. [PubMed: 23856218]

30. Golshayan D, Buhler L, Lechler RI, Pascual M. From current immunosuppressive strategies to clinical tolerance of allografts. Transpl Int. 2007; 20:12. [PubMed: 17181648]

31. Nikolich-Zugich J, Slifka MK, Messaoudi I. The many important facets of T-cell repertoire diversity. Nat Rev Immunol. 2004; 4:123. [PubMed: 15040585] 
32. Lombardi G, Warrens AN, Lechler RI. Anergic T cells act as suppressor cells in vitro. Transplant Proc. 1995; 27:235. [PubMed: 7878982]

33. Wang P, Zheng SG. Regulatory T cells and B cells: implication on autoimmune diseases. Int J Clin Exp Pathol. 2013; 6:2668. [PubMed: 24294353]

34. Salama AD, Womer KL, Sayegh MH. Clinical transplantation tolerance: many rivers to cross. J Immunol. 2007; 178:5419. [PubMed: 17442921]

35. Di, Cocco P.; Bonanni, L.; D’Angelo, M.; Clemente, K.; Greco, S.; Rizza, V., et al. Clinical operational tolerance after solid organ transplantation. Transplant Proc. 2009; 41:1278. [PubMed: 19460538]

36. Calne R, Watson CJ. Some observations on prope tolerance. Curr Opin Organ Transplant. 2011; 16:353. [PubMed: 21666472]

37. Newell KA, Asare A, Kirk AD, Gisler TD, Bourcier K, Suthanthiran M, et al. Identification of a B cell signature associated with renal transplant tolerance in humans. J Clin Invest. 2010; 120:1836. [PubMed: 20501946]

38. Sagoo P, Perucha E, Sawitzki B, Tomiuk S, Stephens DA, Miqueu P, et al. Development of a cross-platform biomarker signature to detect renal transplant tolerance in humans. J Clin Invest. 2010; 120:1848. [PubMed: 20501943]

39. Miller SD, Turley DM, Podojil JR. Antigen-specific tolerance strategies for the prevention and treatment of autoimmune disease. Nat Rev Immunol. 2007; 7:665. [PubMed: 17690713]

40. Getts DR, McCarthy DP, Miller SD. Exploiting apoptosis for therapeutic tolerance induction. J Immunol. 2013; 191:5341. [PubMed: 24244028]

41. Kheradmand T, Wang S, Bryant J, Tasch JJ, Lerret N, Pothoven KL, et al. Ethylenecarbodiimidefixed donor splenocyte infusions differentially target direct and indirect pathways of allorecognition for induction of transplant tolerance. J Immunol. 2012; 189:804. [PubMed: 22696445]

42. Luo X, Pothoven KL, McCarthy D, DeGutes M, Martin A, Getts DR, et al. ECDI-fixed allogeneic splenocytes induce donor-specific tolerance for long-term survival of islet transplants via two distinct mechanisms. Proc Natl Acad Sci U S A. 2008; 105:14527. [PubMed: 18796615]

43. Chen G, Kheradmand T, Bryant J, Wang S, Tasch J, Wang JJ, et al. Intragraft CD11b(+) IDO(+) cells mediate cardiac allograft tolerance by ECDI-fixed donor splenocyte infusions. Am J Transplant. 2012; 12:2920. [PubMed: 22883222]

44. Lutterotti A, Yousef S, Sputtek A, Sturner KH, Stellmann JP, Breiden P, et al. Antigen-specific tolerance by autologous myelin peptide-coupled cells a phase 1 trial in multiple sclerosis. Sci Transl Med. 2013; 5 188ra75.

45. Kuhns MS, Davis MM, Garcia KC. Deconstructing the form and function of the TCR/CD3 complex. Immunity. 2006; 24:133. [PubMed: 16473826]

46. Goto R, You S, Zaitsu M, Chatenoud L, Wood KJ. Delayed anti-CD3 therapy results in depletion of alloreactive T cells and the dominance of Foxp3+ CD4+ graft infiltrating cells. Am J Transplant. 2013; 13:1655. [PubMed: 23750800]

47. Nicolls MR, Aversa GG, Pearce NW, Spinelli A, Berger MF, Gurley KE, et al. Induction of longterm specific tolerance to allografts in rats by therapy with an anti-CD3-like monoclonal antibody. Transplantation. 1993; 55:459. [PubMed: 8456460]

48. You S, Zuber J, Kuhn C, Baas M, Valette F, Sauvaget V, et al. Induction of allograft tolerance by monoclonal CD3 antibodies: a matter of timing. Am J Transplant. 2012; 12:2909. [PubMed: 22882762]

49. Chatenoud L, Waldmann H. CD3 monoclonal antibodies: a first step towards operational immune tolerance in the clinic. Rev Diabet Stud. 2012; 9:372. [PubMed: 23804274]

50. Ippoliti G, D’Armini AM, Lucioni M, Marjieh M, Vigano M. Introduction to the use of belatacept: a fusion protein for the prevention of posttransplant kidney rejection. Biologics. 2012; 6:355. [PubMed: 23055693]

51. Linsley PS, Brady W, Urnes M, Grosmaire LS, Damle NK, Ledbetter JA. CTLA-4 is a second receptor for the B cell activation antigen B7. J Exp Med. 1991; 174:561. [PubMed: 1714933]

52. Ford ML, Larsen CP. Translating costimulation blockade to the clinic: lessons learned from three pathways. Immunol Rev. 2009; 229:294. [PubMed: 19426229] 
53. Birsan T, Hausen B, Higgins JP, Hubble RW, Klupp J, Stalder M, et al. Treatment with humanized monoclonal antibodies against CD80 and CD86 combined with sirolimus prolongs renal allograft survival in cynomolgus monkeys. Transplantation. 2003; 75:2106. [PubMed: 12829920]

54. Haspot F, Seveno C, Dugast AS, Coulon F, Renaudin K, Usal C, et al. Anti-CD28 antibodyinduced kidney allograft tolerance related to tryptophan degradation and TCR class II B7 regulatory cells. Am J Transplant. 2005; 5:2339. [PubMed: 16162181]

55. Lin H, Bolling SF, Linsley PS, Wei RQ, Gordon D, Thompson CB, et al. Long-term acceptance of major histocompatibility complex mismatched cardiac allografts induced by CTLA4Ig plus donorspecific transfusion. J Exp Med. 1993; 178:1801. [PubMed: 8228826]

56. Pearson TC, Alexander DZ, Winn KJ, Linsley PS, Lowry RP, Larsen CP. Transplantation tolerance induced by CTLA4-Ig. Transplantation. 1994; 57:1701. [PubMed: 8016872]

57. Larsen CP, Knechtle SJ, Adams A, Pearson T, Kirk AD. A new look at blockade of T-cell costimulation: a therapeutic strategy for long-term maintenance immunosuppression. Am J Transplant. 2006; 6:876. [PubMed: 16611323]

58. Daoussis D, Andonopoulos AP, Liossis SN. Targeting CD40L: a promising therapeutic approach. Clin Diagn Lab Immunol. 2004; 11:635. [PubMed: 15242934]

59. Hancock WW, Sayegh MH, Zheng XG, Peach R, Linsley PS, Turka LA. Costimulatory function and expression of CD40 ligand, CD80, and CD86 in vascularized murine cardiac allograft rejection. Proc Natl Acad Sci U S A. 1996; 93:13967. [PubMed: 8943044]

60. Larsen CP, Alexander DZ, Hollenbaugh D, Elwood ET, Ritchie SC, Aruffo A, et al. CD40-gp39 interactions play a critical role during allograft rejection Suppression of allograft rejection by blockade of the CD40-gp39 pathway. Transplantation. 1996; 61:4. [PubMed: 8560571]

61. Jiang X, Sun W, Guo D, Cui Z, Zhu L, Lin L, et al. Cardiac allograft acceptance induced by blockade of CD40-CD40L costimulation is dependent on CD4+CD25+ regulatory T cells. Surgery. 2011; 149:336. [PubMed: 20875655]

62. Kawai T, Andrews D, Colvin RB, Sachs DH, Cosimi AB. Thromboembolic complications after treatment with monoclonal antibody against CD40 ligand. Nat Med. 2000; 6:114.

63. Haanstra KG, Sick EA, Ringers J, Wubben JA, Kuhn EM, Boon L, et al. Costimulation blockade followed by a 12-week period of cyclosporine A facilitates prolonged drug-free survival of rhesus monkey kidney allografts. Transplantation. 2005; 79:1623. [PubMed: 15940054]

64. Kinnear G, Jones ND, Wood KJ. Costimulation blockade: current perspectives and implications for therapy. Transplantation. 2013; 95:527. [PubMed: 23129000]

65. Ildstad ST, Sachs DH. Reconstitution with syngeneic plus allogeneic or xenogeneic bone marrow leads to specific acceptance of allografts or xenografts. Nature. 1984; 307:168. [PubMed: 6361574]

66. Sachs DH, Kawai T, Sykes M. Induction of tolerance through mixed chimerism. Cold Spring Harb Perspect Med. 2014; 4

67. Kawai T, Cosimi AB, Spitzer TR, Tolkoff-Rubin N, Suthanthiran M, Saidman SL, et al. HLAmismatched renal transplantation without maintenance immunosuppression. N Engl J Med. 2008; 358:353. [PubMed: 18216355]

68. Kawai T, Sachs DH, Sykes M, Cosimi AB. HLA-mismatched renal transplantation without maintenance immunosuppression. N Engl J Med. 2013; 368:1850. [PubMed: 23656665]

69. Golshayan D, Jiang S, Tsang J, Garin MI, Mottet C, Lechler RI. In vitro-expanded donor alloantigen-specific CD4+CD25+ regulatory T cells promote experimental transplantation tolerance. Blood. 2007; 109:827. [PubMed: 17003369]

70. Tang Q, Bluestone JA, Kang SM. CD4(+)Foxp3(+) regulatory T cell therapy in transplantation. J Mol Cell Biol. 2012; 4:11. [PubMed: 22170955]

71. Lee K, Nguyen V, Lee KM, Kang SM, Tang Q. Attenuation of donor-reactive T cells allows effective control of allograft rejection using regulatory T cell therapy. Am J Transplant. 2014; 14:27. [PubMed: 24354870]

72. Joffre O, Santolaria T, Calise D, Al Saati T, Hudrisier D, Romagnoli P, et al. Prevention of acute and chronic allograft rejection with CD4+CD25+Foxp3+ regulatory T lymphocytes. Nat Med. 2008; 14:88. [PubMed: 18066074] 
73. Pilat N, Baranyi U, Klaus C, Jaeckel E, Mpofu N, Wrba F, et al. Treg-therapy allows mixed chimerism and transplantation tolerance without cytoreductive conditioning. Am J Transplant. 2010; 10:751. [PubMed: 20148810]

74. Tang Q, Bluestone JA. Regulatory T-cell therapy in transplantation: moving to the clinic. Cold Spring Harb Perspect Med. 2013; 3-6

75. Hanson DG, Vaz NM, Maia LC, Hornbrook MM, Lynch JM, Roy CA. Inhibition of specific immune responses by feeding protein antigens. Int Arch Allergy Appl Immunol. 1977; 55:526. [PubMed: 591113]

76. Faria AM, Weiner HL. Oral tolerance: therapeutic implications for autoimmune diseases. Clin Dev Immunol. 2006; 13:143. [PubMed: 17162357]

77. Weiner HL, da Cunha AP, Quintana F, Wu H. Oral tolerance. Immunol Rev. 2011; 241:241. [PubMed: 21488901]

78. Womer KL, Magee CC, Najafian N, Vella JP, Milford EL, Sayegh MH, et al. A pilot study on the immunological effects of oral administration of donor major histocompatibility complex class II peptides in renal transplant recipients. Clin Transplant. 2008; 22:754. [PubMed: 18647327]

79. Sayegh MH, Zhang ZJ, Hancock WW, Kwok CA, Carpenter CB, Weiner HL. Down-regulation of the immune response to histocompatibility antigens and prevention of sensitization by skin allografts by orally administered alloantigen. Transplantation. 1992; 53:163. [PubMed: 1733066]

80. Sayegh MH, Khoury SJ, Hancock WW, Weiner HL, Carpenter CB. Mechanisms of oral tolerance by MHC peptides. Ann N Y Acad Sci. 1996; 778:338. [PubMed: 8610987]

81. Niimi M, Witzke O, Bushell A, Hara M, Morris PJ, Wood KJ. Nondepleting anti-CD4 monoclonal antibody enhances the ability of oral alloantigen delivery to induce indefinite survival of cardiac allografts: oral tolerance to alloantigen. Transplantation. 2000; 70:1524. [PubMed: 11118100]

82. Burke CM, Glanville AR, Theodore J, Robin ED. LUng immunogenicity, rejection, and obliterative bronchiolitis. CHEST J. 1987; 92:547.

83. Gelman AE, Okazaki M, Lai J, Kornfeld CG, Kreisel FH, Richardson SB, et al. CD4+ T lymphocytes are not necessary for the acute rejection of vascularized mouse lung transplants. J Immunol. 2008; 180:4754. [PubMed: 18354199]

84. Aoyama A, Ng CY, Millington TM, Boskovic S, Murakami T, Wain JC, et al. Comparison of lung and kidney allografts in induction of tolerance by a mixed-chimerism approach in cynomolgus monkeys. Transplant Proc. 2009; 41:429. [PubMed: 19249572]

85. Dodd-o JM, Lendermon EA, Miller HL, Zhong Q, John ER, Jungraithmayr WM, et al. CD154 blockade abrogates allospecific responses and enhances CD4(+) regulatory T-cells in mouse orthotopic lung transplant. Am J Transplant. 2011; 11:1815. [PubMed: 21827610]

86. Okazaki M, Gelman AE, Tietjens JR, Ibricevic A, Kornfeld CG, Huang HJ, et al. Maintenance of airway epithelium in acutely rejected orthotopic vascularized mouse lung transplants. Am J Respir Cell Mol Biol. 2007; 37:625. [PubMed: 17717320]

87. Shoji T, Muniappan A, Guenther DA, Wain JC, Houser SL, Hoerbelt R, et al. Long-term acceptance of porcine pulmonary allografts without chronic rejection. Transplant Proc. 2005; 37:72. [PubMed: 15808551]

88. Shoji T, Sahara H, Muniappan A, Guenther DA, Houser SL, Pujara AC, et al. An MHC class II disparity raises the threshold for tolerance induction in pulmonary allografts in miniature swine. Transplant Proc. 2006; 38:3268. [PubMed: 17175245]

89. Zhao Y, Gillen JR, Harris DA, Kron IL, Murphy MP, Lau CL. Treatment with placenta-derived mesenchymal stem cells mitigates development of bronchiolitis obliterans in a murine model. $\mathrm{J}$ Thorac Cardiovasc Surg. 2013; 147:1668. [PubMed: 24199758]

90. Jungraithmayr W, Jang JH, Schrepfer S, Inci I, Weder W. Small animal models of experimental obliterative bronchiolitis. Am J Respir Cell Mol Biol. 2013; 48:675. [PubMed: 23392572]

91. Okazaki M, Krupnick AS, Kornfeld CG, Lai JM, Ritter JH, Richardson SB, et al. A mouse model of orthotopic vascularized aerated lung transplantation. Am J Transplant. 2007; 7:1672. [PubMed: 17511692]

92. Mares DC, Heidler KM, Smith GN, Cummings OW, Harris ER, Foresman B, et al. Type V collagen modulates alloantigen-induced pathology and immunology in the lung. Am J Respir Cell Mol Biol. 2000; 23:62. [PubMed: 10873154] 
93. Yamada Y, Sekine Y, Yoshida S, Yasufuku K, Petrache I, Benson HL, et al. Type V collageninduced oral tolerance plus low-dose cyclosporine prevents rejection of MHC class I and II incompatible lung allografts. J Immunol. 2009; 183:237. [PubMed: 19542435] 
First Transplants 2000-2012

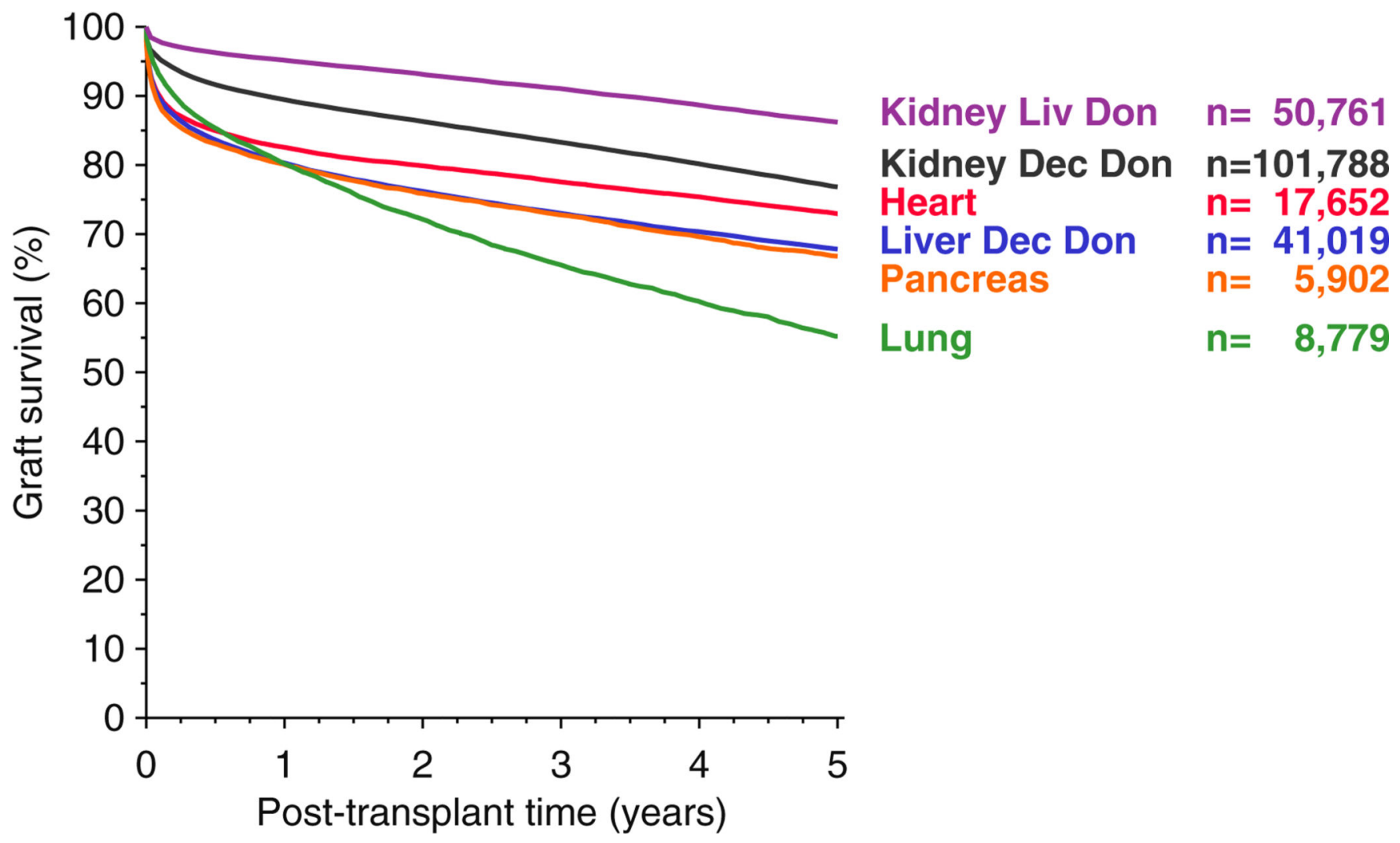

Fig. 1.

Graft survival: collaborative transplant study data comparing graft survival for solid organ allografts. Used with permission. 


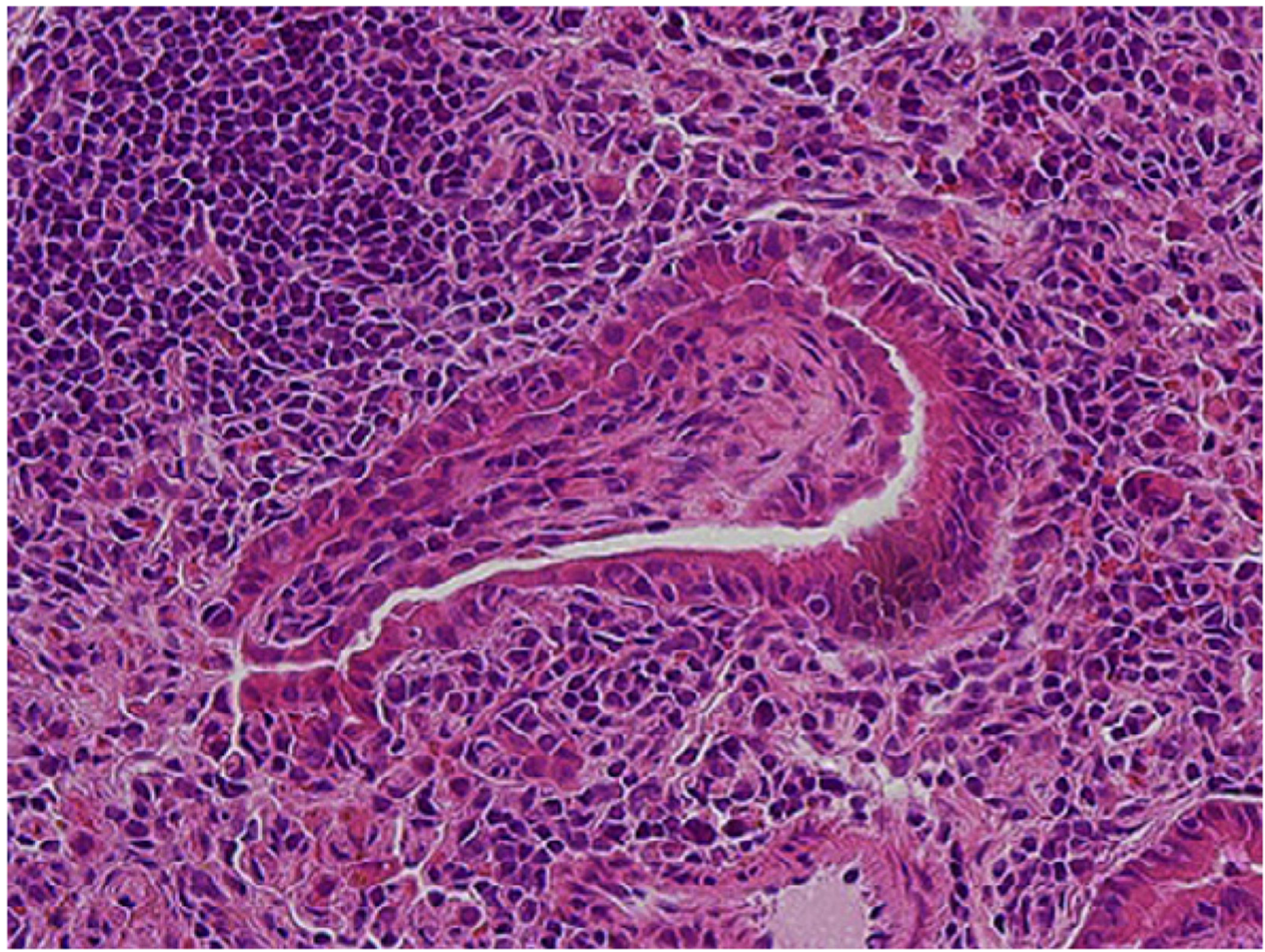

Fig. 2.

Obliterative bronchiolitis histologic specimen: lung specimen demonstrating characteristic occlusion of the bronchiolar lumen in obliterative bronchiolitis. 


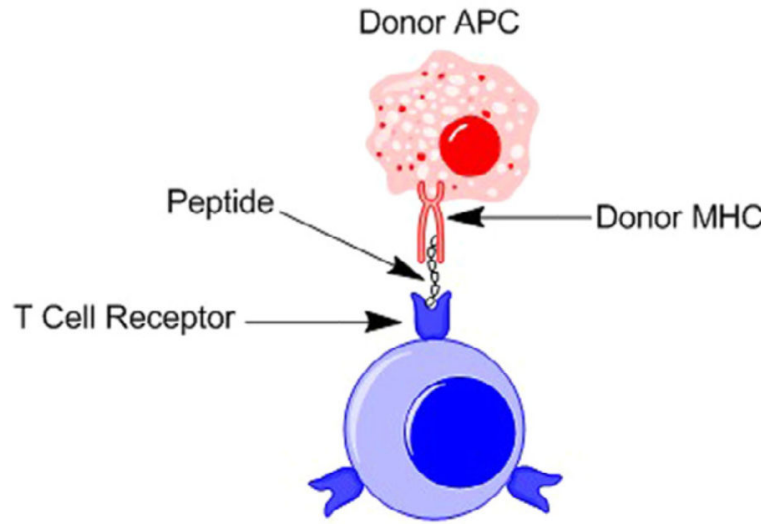

Recipient T Cell
Recipient APC

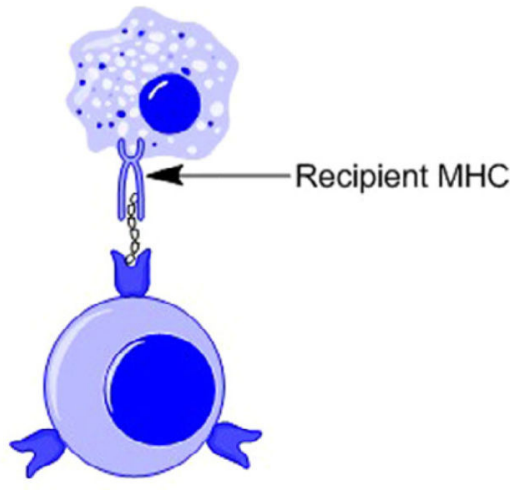

Recipient T Cell
Recipient APC

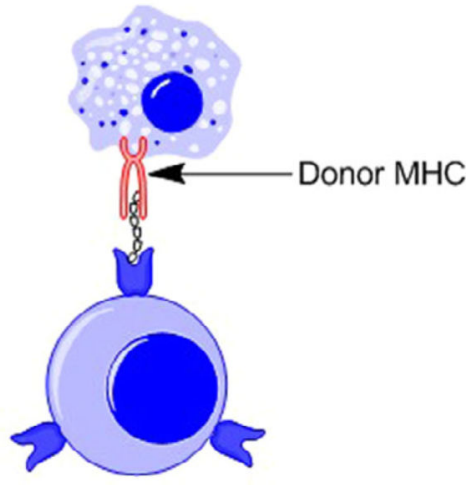

Recipient T Cell

\section{Direct}

Indirect

\section{Semidirect}

Fig. 3.

Alloantigen recognition: direct recognition of antigen presented by allogeneic MHC on donor APC, indirect recognition of antigen presented by recipient MHC on recipient APC, and semidirect recognition of antigen presented by allogeneic MHC on recipient APC. 


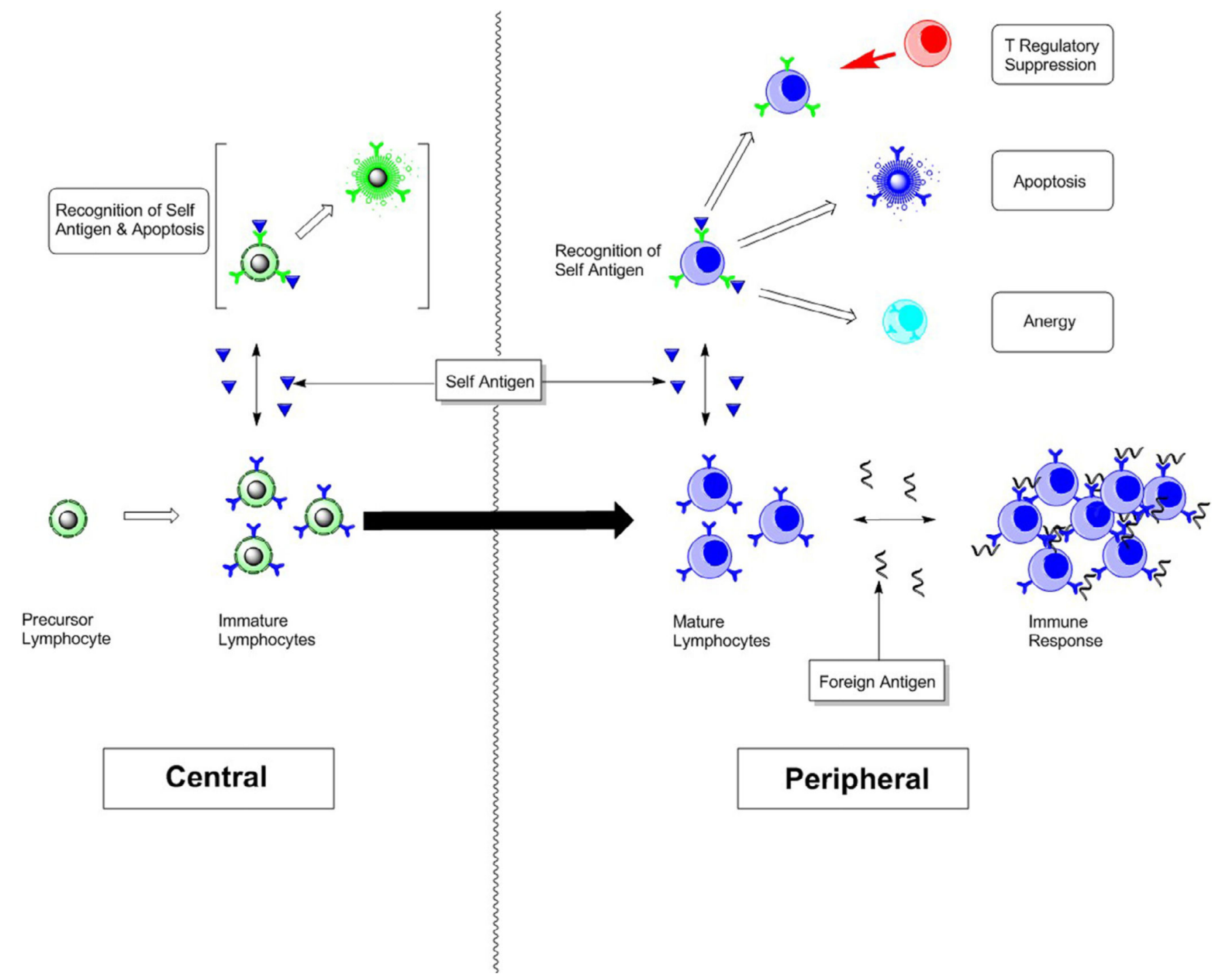

Fig. 4.

Central and peripheral immune tolerance: central tolerance illustrated by immature lymphocyte recognition of self antigen resulting in apoptosis. Peripheral tolerance illustrated by mature lymphocyte recognition of self antigen resulting in $\mathrm{T}$ regulatory cell suppression, apoptosis, or anergy. 